\title{
PEMANFAATAN MOLASE UNTUK PEMBUATAN LEUKO ZAT WARNA INDIGO
}

\author{
USE OF MOLASSES IN REDUCTION OF INDIGO DYE
}

\author{
Ika Natalia Mauliza ${ }^{1 *}$, Khabal Khuludt $^{1}$, Hiqma Aurinda Pratiwi ${ }^{1}$ \\ 1. Politeknik STTT, Bandung, 40272, Indonesia \\ *Email : nataliamauliza@gmail.com
}

\begin{abstract}
ABSTRAK
Zat warna indigo dapat digunakan untuk mewarnai serat selulosa. Zat warna indigo tidak larut dalam air, sehingga harus diubah dalam bentuk leuko zat warna indigo menggunakan reduktor. Reduktor yang digunakan umumnya natrium hidrosulfit yang sensitif terhadap udara dan kelembaban. Reduktor yang dapat digunakan sebagai alternatif pengganti natrium hidrosulfit adalah molase. Molase merupakan limbah produksi gula tebu yang mengandung campuran glukosa dan fruktosa. Pembentukan leuko zat warna indigo menggunakan molase dilakukan dengan rasio zat warna dan molase $1: 1-1: 5$ pada suhu $70^{\circ} \mathrm{C}$ selama 10 menit. Leuko zat warna yang dihasilkan kemudian digunakan untuk mencelup kain kapas. Molase yang digunakan memiliki kandungan gula pereduksi $17,1747 \%$. Leuko zat warna diamati sifat kelarutan, potensial reduksi oksidasi, serta daya celup pada kapas. Penggunaan molase pada pembentukan leuko zat warna indigo berpengaruh terhadap kelarutan, potensial reduksi oksidasi, dan daya celup zat warna indigo yang makin baik seiring dengan pengingkatan rasio zat warna dengan molase. Kenaikan rasio molase pada pembentukan leuko, meningkatkan ketuaan warna dan kerataan warna hasil pencelupan. Penggunaan molase tidak berpengaruh terhadap ketahanan luntur warna terhadap pencucian dan gosokkan. Mutu leuko dan hasil pencelupan zat warna indigo yang diproses menggunakan molase lebih rendah dibandingkan pembentukan leuko zat warna indigo menggunakan glukosa murni.
\end{abstract}

Kata kunci : gula pereduksi, indigo, leuko, molase, pencelupan

\begin{abstract}
Indigo dye can be used to dye cellulose fibers. Indigo dye insoluble in water, so it must be converted into leuco by reducing agent. The reducing agent commonly used is sodium hydrosulfite which is sensitive to air and moisture. Reductors that can be used as an alternative to sodium hydrosulfite are molasses. Molasses is a sugar cane production waste consists of glucose and fructose. The treatment of indigo dye using molasses is carried out by comparing the dye and molasses $1: 1-1: 5$ at $70^{\circ} \mathrm{C}$ for 10 minutes. Indigo dye solution used to dye cotton fabrics. The molasses used consists of $17,1747 \%$. reducing sugar. Indigo dyes solution were observed for their solubility, oxidation reduction potential, and dyeability on cotton. The use of molasses in indigo dyestuffs has an effect on the solubility, oxidation reduction potential, and dyeability of indigo dyes which are getting better with the increase in the ratio of molasses. Addition
\end{abstract}


of molasses concentration in the indigo dye dissolution, increases the color strength and the evenness of the dyeing result. The use of molasses has no effect on the color fastness of washing and rubbing. Quality of Indigo dyes solution processed using molasses was lower than using pure glucose.

Key words: dyeing, indigo, leuco, molasses, reducing sugar

\section{Pendahuluan}

Indigo adalah salah satu zat warna alam yang memiliki karakteristik berwarna biru, tidak larut dalam air, dan memiliki ketahanan luntur terhadap sinar dan pencucian sangat baik. Indigo termasuk zat warna alam yang paling tua dan penerapannya sebagai pewarna kemudian diadopsi dalam bentuk zat warna buatan golongan zat warna bejana. Warna biru zat warna indigo berasal dari zat indican/isatan yang terkandung dalam tanaman Indigofera/Isatis.

Pembuatan zat warna indigo diawali dengan perendaman daun dalam air untuk mengeluarkan senyawa aktif penghasil zat warna. Indican yang terkekstrak kemudian diubah menjadi indoxyl dan glukosa oleh enzim. Indoxyl akan kembali ke bentuk senyawa berwarna biru jika dioksidasi (Purnama, 2017). Reaksi pembentukan indigo dari indican maupun isatan dapat dilihat pada Gambar 1.

Zat warna indigo tidak memiliki kelarutan yang baik dalam air. Zat warna indigo tidak dapat terserap pada kapas dalam bentuk zat warna yang tidak larut. Peningkatan daya celup zat warna indigo pada serat kapas dapat dilakukan dengan mengubah zat warna indigo menjadi bentuk leuko yang larut dalam air (Mayangsari dkk., 2012).

Penggunaan Indigo sebagai pewarna tekstil harus melalui pembentukan leuko zat warna yang larut dalam air melalui proses pereduksian menggunakan reduktor kuat seperti natrium hidrosulfit $\left(\mathrm{Na}_{2} \mathrm{~S}_{2} \mathrm{O}_{4}\right)$ pada suasana alkali (Komboonchoo dkk., 2009). 


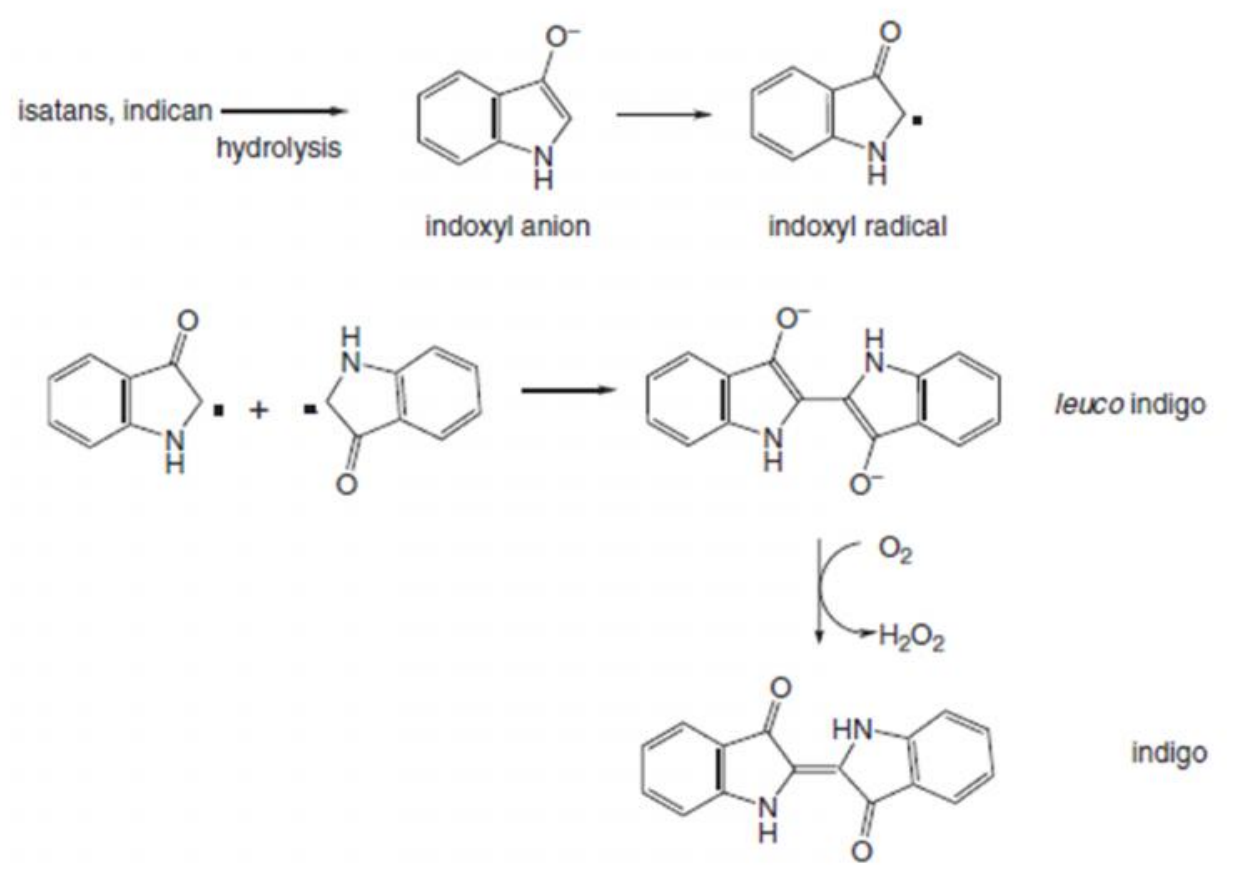

Sumber : Bechtold, Thomas \& Rita Mussak, Handbook of Natural Colorants, Austria, 2009, halaman 112.

Gambar 1. Reaksi pembentukan indigo dari indoxyl yang dihasilkan oleh hidrolisis prekusor indigo

Penggunaan natrium hidrosulfit pada proses tekstil kurang disukai karena bersifat tidak stabil dan mudah teroksidasi oleh udara (Blackburn dkk., 2009). Natrium hidrosulfit harus cepat digunakan dan disimpan dalam keadaan tertutup untuk menjaga daya reduksinya. Natrium hidrosulfit sensitif terhadap paparan udara dan kelembaban, sehingga harus disimpan dalam kondisi tertutup rapat. (https://fscimage.fishersci.com/msds/2 1290.htm diakses pada 25 November 2020) Selain itu, penggunaan natrium hidrosulfit dapat menimbulkan dampak yang kurang baik terhadap lingkungan karena berracun dan korosif pada saluran pembuangan limbah (Meksi dkk., 2012). Hal ini menjadi kendala penggunaan natrium hidrosulfit di industri.

Zat warna indigo banyak digunakan di Industri Kecil Menengah. Proses pencelupan di Industri Kecil Menengah tidak berlangsung secara kontinyu sehingga menyebabkan perlunya pemilihan bahan yang memiliki sifat fleksibel, stabil, dan penanganan yang mudah. Selain itu, beberapa industri memiliki kepedulian yang tinggi terhadap lingkungan sehingga sangat 
memperhatikan jenis bahan yang digunakan untuk proses produksi.

Terdapat beberapa alternatif reduktor yang dapat digunakan untuk pembuatan leuko, antara lain glukosa dan fruktosa yang termasuk golongan monosakarida. Glukosa dan fruktosa dikenal sebagai gula pereduksi. Penggunaan gula pereduksi sebagai zat pereduksi memiliki kelebihan tidak beracun, tidak mudah teroksidasi oleh udara sehingga dapat disimpan dalam jangka waktu yang lama dan juga bersifat biodegradable (Blackbum dkk., 2004).

Gula pereduksi mengandung gugus aldehid atau keton. Gula pereduksi termasuk reduktor lemah. Glukosa hanya mengembangkan potensi redoks pada suhu tinggi dan dalam kondisi alkalinitas tinggi. Potensi redoks glukosa tergantung pada suhu dan mencapai maksimum pada sekitar 70 ${ }^{\circ} \mathrm{C}$ (Aleem, 2013). Karakteristik pereduksian tersebut berbeda dengan natrium hidrosulfit yang dapat mereduksi pada suhu kamar.

Proses pereduksian terjadi karena adanya gugus aldehid yang akan menjadi asam karboksilat dan menghasilkan $\mathrm{H}$-nascent. $\mathrm{H}$-nascent tersebut akan mereduksi zat warna indigo menjadi senyawa leuko yang larut.

$$
\mathrm{R}-\mathrm{CHO}+\mathrm{H} 2 \mathrm{O} \rightarrow \mathrm{RCOOH}+2 \mathrm{Hn}
$$
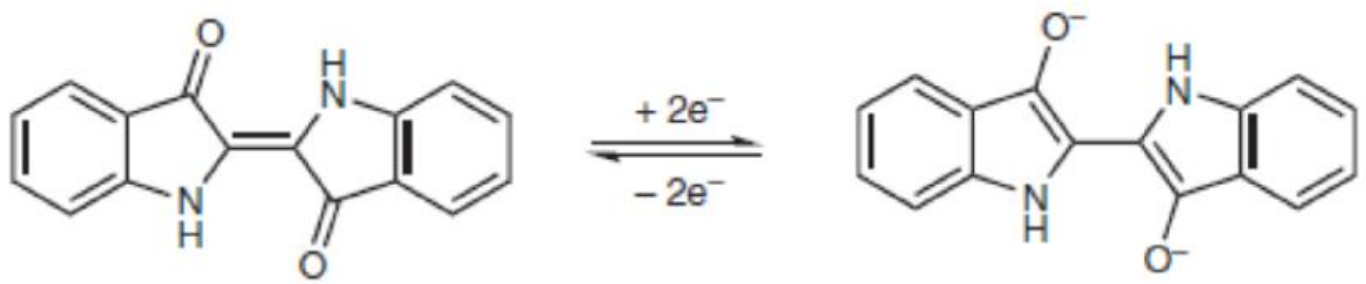

Sumber: Stephen M. Burkinshaw. Physico-chemical-Aspects of Textile Colaration. University of Leals. 2016

\section{Gambar 2. Oksidasi reduksi indigo}

Molase adalah sirup kental berwarna cokelat, produk sampingan dari industri pembuat gula, mengandung sukrosa dan gula pereduksi (glukosa dan fruktosa), gula pereduksi yang memberikan efek perlindungan jangka panjang pada leuko indigo, 
mencegahnya teroksidasi secara signifikan di udara (Blackburn, 2009).

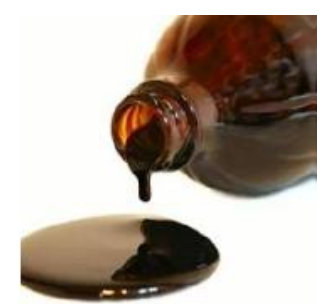

Sumber:https://id.images.search.yahoo.co $\mathrm{m} / \mathrm{yhs} / \mathrm{search}$ ? $=$ molase+gambar diakses pada 20 Oktober 2020, pukul 20.00

Gambar 3. Molase

Molase merupakan cairan kental yang didapat pada pemisahan kristal gula tebu. Molase mengandung gula, asam amino dan mineral. Molase mengandung kadar gula yang tinggi. Komposisi sukrosa dan gula reduksi dalam molase berada pada rentang nilai antara 50 - $65 \%$ dengan $25-40$ $\%$ terdiri dari sukrosa dan $12-35 \%$ gula reduksi (Rochani dkk., 2016).

Daya reduksi suatu reduktor sangat berpengaruh terhadap kemampuan reduktor tersebut untuk mereduksi suatu senyawa. Tiga jenis reduktor yang umum digunakan pada pembuatan leuko mulai dari daya reduksi tertinggi hingga terrendah antara lain natrium hidrosulfit, glukosa, dan natrium sulfida. Pada konsentrasi reduktor $1 \mathrm{~g} / \mathrm{L}$ potensial reduksi masing-masing reduktor berturut-turut, yaitu natrium hidrosulfit $-805 \mathrm{mV}$, glukosa -614 mV, dan natrium sulfida $550 \mathrm{mV}$. (Baffoun, 2015)

Kekuatan reduksi dari glukosa dan fruktosa hampir sama, sedangkan kekuatan molase lebih tinggi 1,5 kalinya (Shukla dan Roshan, 2004). Oleh karena itu, molase berpotensi dijadikan zat pereduksi pada proses pelarutan zat warna indigo sebagai alternatif pengganti reduktor $\mathrm{Na}_{2} \mathrm{~S}_{2} \mathrm{O}_{4}$ yang lebih hemat biaya dan ramah lingkungan. Selain itu, molase merupakan limbah pabrik gula yang keberadaannya cukup melimpah, murah, dan belum termanfaatkan dengan baik.

$\mathrm{pH}$ proses pencelupan zat warna indigo berpengaruh terhadap ketuaan warna. $\mathrm{pH}$ alkalis dibutuhkan pada proses pencelupan untuk menstabilkan pereduksian zat warna indigo. Ketuaan warna terbaik pada pencelupan zat warna indigo diperoleh pada $\mathrm{pH} 10,5$ 11,5 (Mayangsari dkk., 2012).

Zat warna indigo yang telah larut mempunyai afinitas terhadap serat tekstil, diantaranya serat kapas. Zat warna indigo dan serat kapas berinteraksi melalui ikatan hidrogen dan ikatan sekunder yaitu gaya Van der Waals. 
Pencelupan kapas dengan zat warna indigo terdiri dari empat tahap, yaitu (1) Pelarutan zat warna indigo (pembuatan leuko zat warna), (2) Pencelupan serat kapas dengan senyawa leuko zat warna indigo, (3) Oksidasi senyawa leuko zat warna indigo menjadi senyawa zat warna indigo yang tidak larut kembali, (4) Pencucian.

Pencelupan serat kapas dengan zat warna indigo menggunakan metode perendaman dilakukan pada suhu ruang. Pencelupan harus memperhatikan proses perendaman agar reaksi oksidasi setempat tidak terjadi. Leuko zat warna indigo dioksidasi membentuk zat warna yang tidak larut seperti di awal proses. Pada proses oksidasi terjadi fiksasi zat warna dengan serat karena zat warna telah diubah kembali menjadi tidak larut dalam air. Setelah proses pencelupan dan oksidasi, dilakukan proses pencucian dengan sabun untuk menghilangkan pigmen indigo yang menempel pada permukaan serat (Djufri dkk., 1976).

Molase mengandung glukosa sebagai salah satu gula pereduksi. Pencelupan zat warna indigo (Indigofera tinctoria) dengan pada berbagai variasi konsentrasi menghasilkan peningkatan ketuaan dan kerataan warnanya seiring kenaikan konsentrasi glukosa (Shabrina, 2019)

Pereduksian zat warna indigo menggunakan molase dengan rasio 1:2 terhadap pasta indigo Strobilantes cusia dan Indigofera tinctoria mampu menghasilkan pewarnaan batik berwarna biru tua (Arta, 2019). Pada penelitian tersebut, belum dipelajari secara spesifik, pengaruh rasio zat warna dan molase terhadap pembentukan leuco maupun dampaknya terhadap warna hasil pencelupan zat warna indigo yang diteliti.

Makin tinggi konsentrasi penggunaan molase sebagai reduktor maka kelarutan indigo akan lebih tinggi. Kelarutan zat warna berpengaruh terhadap ketuaan warna, kerataan warna, ketahanan luntur warna terhadap pencucian dan ketahanan luntur warna terhadap gosokan yang lebih baik.

Pada penelitian ini, molase digunakan untuk mereduksi zat warna indigo dengan berbagai rasio zat warna indigo dan molase untuk mendapatkan rasio berat zat warna dan reduktor yang dapat direkomendasikan untuk menghasilkan pencelupan dengan 
kualitas warna dan ketahanan luntur yang baik. Mutu pewarnaan kemudian dibandingkan dengan penggunaan reduktor glukosa murni.

\section{Bahan dan Metoda}

Bahan yang digunakan pada penelitian ini adalah zat warna indigo (Indigofera tinctorial) dari salah satu perkebunan di daerah Jawa Tengah dengan kemurnian indigo 18\%, molase dari distributor molase di kawasan Kabupaten Bandung dengan kadar air 76\%, glukosa p.a. (Merck), kain kapas tenunan polos dengan berat kain 99,23 $\mathrm{g} / \mathrm{m}^{2}, \mathrm{NaOH}$ flakes teknis (Sopyan Jaya Cemerlang). Proses pembuatan leuko zat warna indigo dilakukan di Laboratorium Kimia-Fisika Politeknik STTT Bandung. Penelitian yang dilakukan melalui tahapan sebagai berikut :
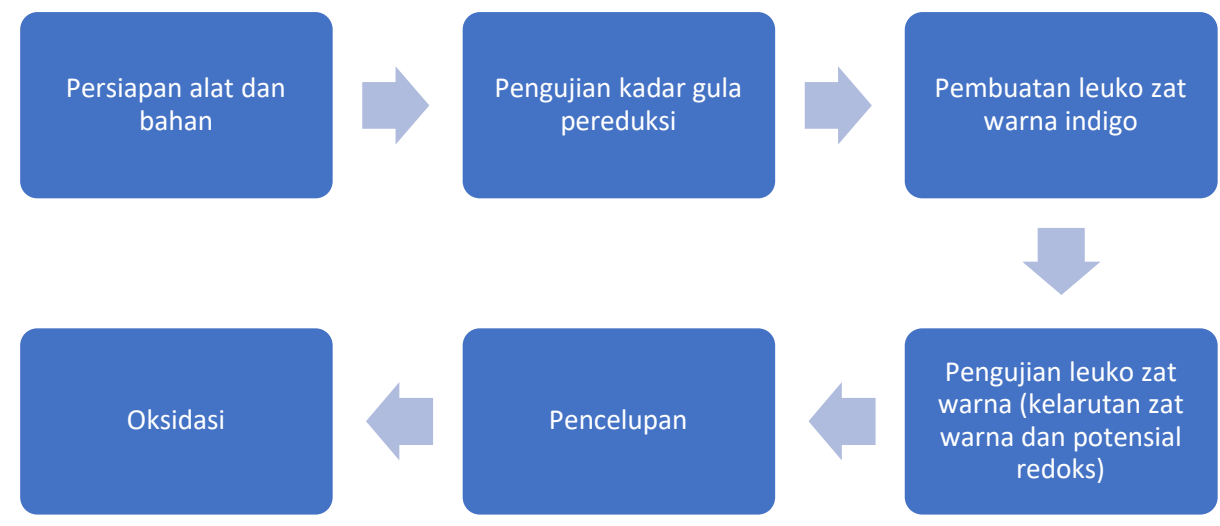

Pengujian leuko zat

warna (kelarutan zat

warna dan potensial

$$
\text { redoks) }
$$
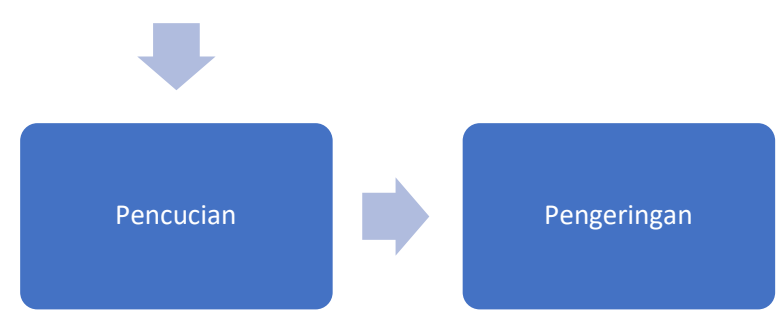

Pengujian larutan sisa

pencelupan (potensial

redoks) dan kain hasil

pencelupan

\section{Gambar 4. Diagram alir penelitian}

Pengujian kandungan gula pereduksi pada molase dilakukan di laboratorium teknologi pangan Fakultas Teknik Universitas Pasundan menggunakan metode Luff Schoorl. Kelarutan zat warna indigo dilakukan melalui pengamatan secara visual. Potensial redoks sebelum dan setelah pencelupan dilakukan menggunakan pH meter Boeco BT 600.

Pembuatan leuko zat warna indigo menggunakan reduktor molase dan glukosa menggunakan resep sebagai berikut : 
Zat warna indigo

Rasio zat warna indigo terhadap molase / glukosa

$\mathrm{pH}$

Liquor Ratio (zat warna indigo : air)

Suhu

Waktu

Leuko yang dihasilkan digunakan seluruhnya untuk mencelup kain kapas dengan rasio (liquor ratio) $1: 50$. Pencelupan kain kapas dengan leuko zat warna indigo dilakukan pada suhu $30^{\circ} \mathrm{C}$ selama 10 menit dengan metode

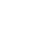

$: 5 \mathrm{~g} / \mathrm{l}$

$: 1: 1 ; 1: 2 ; 1: 3 ; 1: 4 ;$ dan $1: 5$

$: 11,5$ (diatur oleh $\mathrm{NaOH} 1 \%$ )

$: 1: 100$

$: 70{ }^{\circ} \mathrm{C}$

: 10 menit

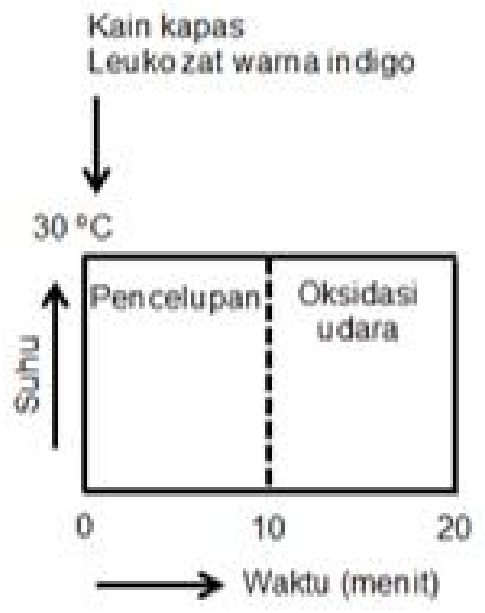

Gambar 5. Skema proses pencelupan kain kapas dengan zat warna indigo

Pengujian ketuaan warna dan kerataan warna dilakukan menggunakan spektrofotometer Minolta CM3600D. Pengujian ketahanan luntur warna terhadap pencucian mengacu pada SNI ISO 105-C06:2010, ketahanan luntur warna terhadap gosokan mengacu pada SNI ISO 105-X12:2012, dan penilaian skala abu-abu untuk exhaust, kemudian dilakukan proses oksidasi dengan metode airing selama 10 menit. Proses pencelupan dan oksidasi dilakukan sebanyak 3 kali pengulangan. 
3.1 Kandungan gula pereduksi pada molase

3.2 Pembuatan leuko zat warna indigo

Kandungan gula pereduksi yang terdapat pada molase yang digunakan pada penelitian ini adalah 17,1747\%. Kandungan gula pereduksi yang terhitung adalah campuran glukosa dan fruktosa.

Zat warna indigo diubah menjadi leuko yang larut dengan rasio berat zat warna terhadap leuko $1: 1 ; 1: 2$; $1: 3 ; 1: 4$; dan $1: 5$. Hasil pengamatan kelarutan zat warna indigo dapat dilihat pada Gambar 6.

\begin{tabular}{|ccccccc|}
\hline $\begin{array}{c}\text { Tanpa } \\
\text { reduktor }\end{array}$ & ZW : & ZW : & ZW : & ZW : & ZW : & ZW : \\
& $1: 1$ & Molase & Molase & Molase & Molase & glukosa \\
& & $1: 2$ & $1: 3$ & $1: 4$ & $1: 5$ & $1: 2$ \\
& & & & & & \\
& & & & & & \\
\hline
\end{tabular}

Gambar 6. Hasil uji pelarutan zat warna indigo menggunakan molase dan glukosa

Pembentukan leuko zat warna indigo pada Gambar 6 memperlihatkan bahwa makin tinggi rasio zat warna dan molase yang digunakan membuat kelarutan zat warna alam indigo makin tinggi. Pada rasio 1:1 dan rasio 1:2, leuko berwarna biru, keruh dan terdapat banyak endapan. Leuko zat warna indigo yang dibuat dengan rasio $1: 3$ dan 1:5 menghasilkan leuko zat warna indigo berwarna kuning kecoklatan, tidak keruh, dan sisa endapan tidak terlalu banyak. Pada salah satu rasio yang menggunakan molase dan glukosa yang sama, kelarutan zat warna indigo pada molase lebih rendah dibandingkan glukosa. 


\subsection{Potensial redoks}

Potensial redoks larutan zat warna indigo yang diproses menggunakan molase dan glukosa sebelum dan setelah proses pencelupan dapat dilihat pada Tabel 1.

Tabel 1. Potensial redoks larutan zat warna indigo sebelum dan setelah pencelupan

\begin{tabular}{|c|c|c|c|c|}
\hline No. & Reduktor & $\begin{array}{c}\text { Rasio ZW : } \\
\text { Molase }\end{array}$ & $\begin{array}{c}\text { Eo max (mV) } \\
\text { sebelum } \\
\text { pencelupan }\end{array}$ & $\begin{array}{c}\text { Eo max (mV) } \\
\text { setelah } \\
\text { pencelupan }\end{array}$ \\
\hline 1 & Molase & $1: 1$ & $-255,5$ & $-250,8$ \\
\hline 2 & Molase & $1: 2$ & $-256,3$ & $-251,6$ \\
\hline 3 & Molase & $1: 3$ & $-260,9$ & $-253,9$ \\
\hline 4 & Molase & $1: 4$ & $-262,3$ & $-258,7$ \\
\hline 5 & Molase & $1: 5$ & $-263,5$ & $-260,2$ \\
\hline 6 & Glukosa & $1: 1$ & $-237,7$ & $-228,6$ \\
\hline 7 & Glukosa & $1: 2$ & $-239,8$ & $-232,3$ \\
\hline 8 & Glukosa & $1: 3$ & $-243,1$ & $-238,8$ \\
\hline 9 & Glukosa & $1: 4$ & $-241,8$ & $-233,5$ \\
\hline 10 & Glukosa & $1: 5$ & $-240,7$ & $-232,9$ \\
\hline
\end{tabular}

Pengujian potensial redoks masing-masing pereduksi dilakukan dengan menggunakan alat pH meter (Beoco BT 600, Germany) pada suhu ruang. Hasil pengujian potensial redoks dapat dilihat pada Tabel 1. Nilai potensial redoks yang paling negatif terdapat pada larutan zat warna indigo yang direduksi menggunakan reduktor molase pada rasio 1:5 dengan nilai $-263,5 \mathrm{mV}$. Setiap jenis reduktor dengan berbagai rasio berat memiliki perbedaan kemampuan reduksi. Molase memiliki kemampuan reduksi yang lebih 
kuat dibandingkan dengan reduktor

glukosa karena memiliki

kandungan dua gula pereduksi yaitu glukosa dan fruktosa. Nilai potensial redoks setelah tiga kali pencelupan tidak jauh berbeda dengan sebelum pencelupan, yang berarti larutan zat warna tersebut masih dapat dilakukan untuk proses pencelupan walaupun kemampuan mereduksinya sudah menurun.

\subsection{Kain hasil pencelupan}

Kain hasil pencelupan zat warna indigo yang dilarutkan menggunakan molase dan glukosa dapat dilihat pada Tabel 2.

Tabel 2. Kain kapas yang dicelup menggunakan zat warna indigo yang direduksi oleh molase dan glukosa

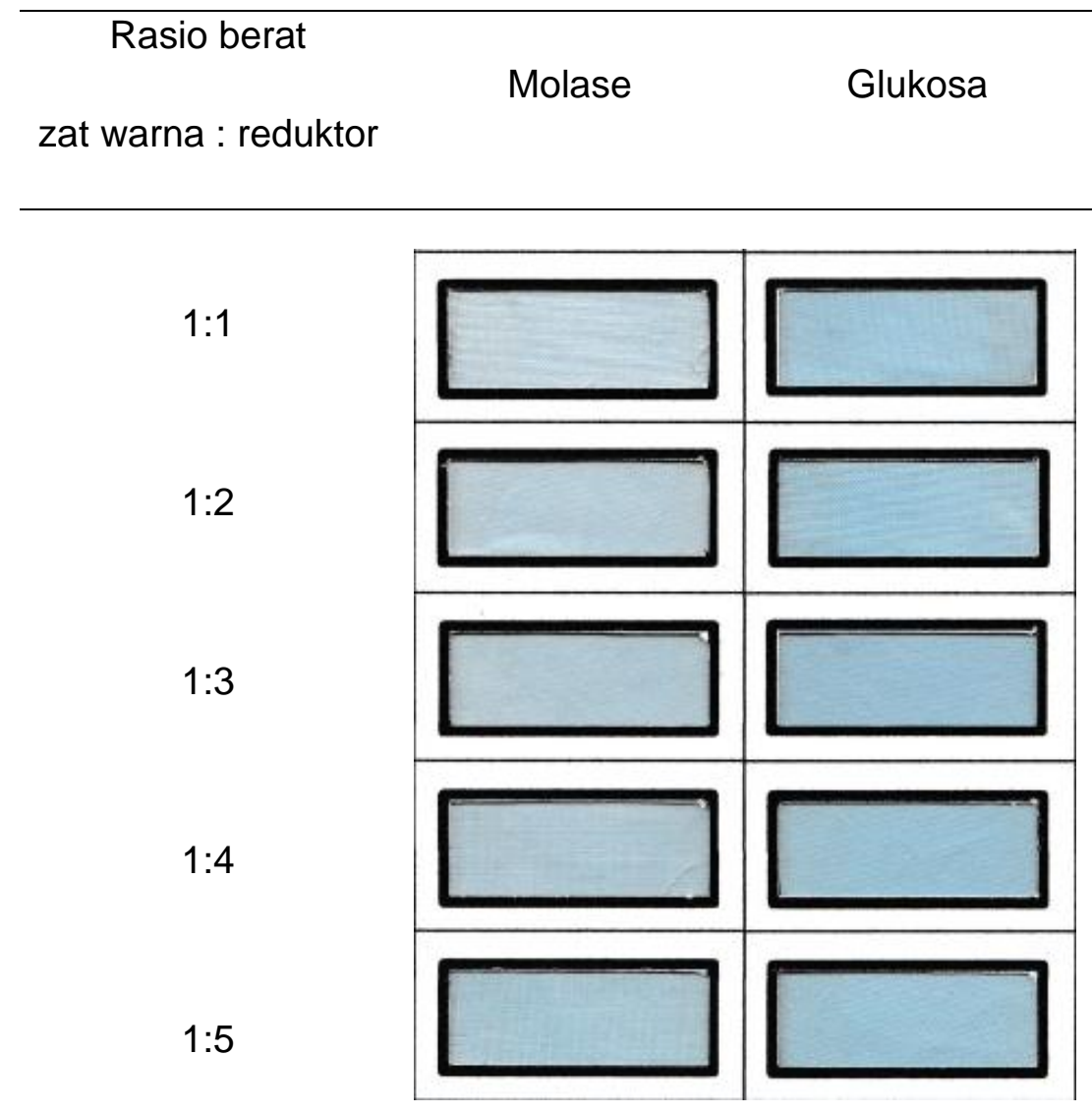


Berdasarkan hasil pengamatan visual kain kapas yang dicelup menggunakan larutan leuko dengan rasio berat zat warna dan molase, terlihat bahwa makin tinggi rasio, menghasilkan warna biru yang lebih tua. Sementara itu, ketuaan warna kain yang dicelup menggunakan leuko yang dibuat oleh glukosa lebih tua pada rasio berat antara zat warna dan reduktor yang sama.

Pengukuran ketuaan warna pada hasil pencelupan kain kapas dengan zat warna indigo dilakukan menggunakan spektrofotometer. Hasil pengukuran ketuaan warna terhadap kain kapas yang dicelup menggunakan zat warna indigo dengan rasio jenis dan variasi konsentrasi reduktor pada $\lambda$ maksimum $660 \mathrm{~nm}$ dapat dilihat pada Tabel 3. Zat warna indigo memiliki sifat yang tidak larut dalam air, sehingga dalam penggunaannya harus diubah terlebih dahulu menjadi bentuk leuko yang larut dalam air dengan penambahan reduktor molase dan glukosa. Leuko zat warna indigo yang telah larut mempunyai afinitas terhadap serat tekstil sehingga terjadi ikatan hidrogen dan ikatan sekunder yaitu gaya Van der Waals dengan serat. Setelah proses pencelupan, dilakukan proses oksidasi dengan udara. Pada proses oksidasi terjadi fiksasi zat warna dengan serat karena zat warna telah diubah kembali menjadi tidak larut dalam air. Warna yang semakin tua menunjukkan banyaknya leuko zat warna indigo yang dihasilkan dan terserap pada kain.

3.5 Ketuaan dan kerataan warna hasil pencelupan

Ketuaan dan kerataan warna hasil pencelupan zat warna indigo yang telah direduksi menggunakah molase dan glukosa dapat dilihat pada Gambar 7. 


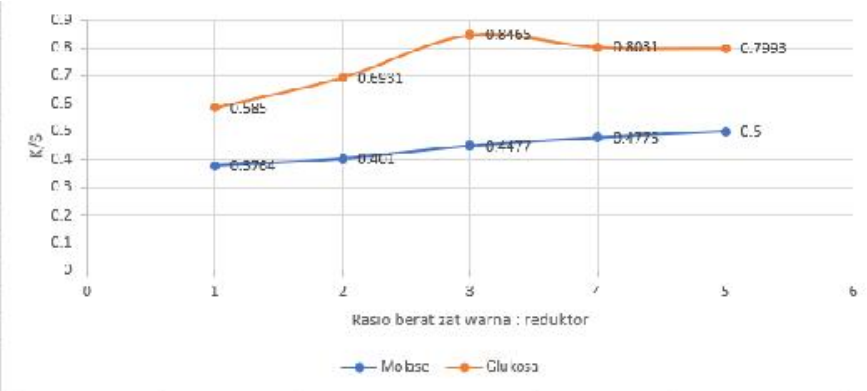

(a)

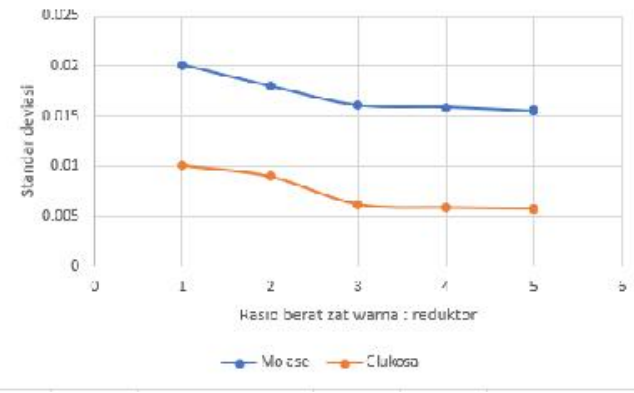

(b)

Gambar 7 Grafik ketuaan warna (a) dan kerataan warna (b) hasil pencelupan zat warna indigo pada panjang gelombang maksimum $660 \mathrm{~nm}$

Berdasarkan hasil pengukuran, jenis dan rasio berat zat warna dan reduktor mempengaruhi ketuaan warna. Hal ini dapat dilihat dari hasil yang didapat bahwa peningkatan rasio berat zat warna dan molase memberikan ketuaan warna yang semakin meningkat hingga rasio 1 : 5. Penurunan nilai $\mathrm{K} / \mathrm{S}$ pada rasio glukosa 1:4 terjadi karena zat warna terlalu larut sehingga stabil di dalam air. Zat warna akan terdispersi sempurna yang menyebabkan ikatan medium di air menjadi kuat, sehingga penyerapan menjadi berkurang. Hal ini berarti daya penyerapan optimum glukosa berada pada rasio berat zat warna dan reduktor 1:3.

Kerataan warna terhadap kain kapas yang dicelup menggunakan zat warna indigo dengan rasio berat antara zat warna dan reduktor pada $\lambda$ maksimum $660 \mathrm{~nm}$ pada lima titik yang berbeda. Jenis dan rasio berat zat warna dan reduktor mempengaruhi kerataan warna. Kerataan warna yang paling baik yaitu pada rasio berat 1 : 5 menggunakan reduktor glukosa dengan standar deviasi sebesar 0,0058 . Hal ini dapat disebabkan karena semakin banyak konsentrasi reduktor glukosa yang digunakan maka zat warna akan terdispersi dengan baik di dalam air sehingga kerataan warna yang dihasilkan lebih baik. Untuk penggunaan reduktor molase, kerataan warna paling baik didapatkan pada rasio berat zat warna dan molase $1: 5$.

\subsection{Ketahanan luntur warna}

Nilai perubahan dan penodaan warna kain pelapis hasil pengujian ketahanan luntur warna terhadap pencucian dan gosokkan berturut- 
turut dapat dilihat pada Tabel 3 dan

Tabel 4.

Tabel 3. Hasil uji ketahanan luntur warna terhadap pencucian

\begin{tabular}{ccccc}
\hline \multirow{2}{*}{ Reduktor } & Konsentrasi & $\begin{array}{c}\text { Perubahan } \\
\text { warna }\end{array}$ & \multicolumn{2}{c}{ Nilai penodaan warna } \\
\cline { 4 - 5 } & & & Kapas & Wol \\
\hline Molase & $1: 1$ & $4-5$ & 5 & 5 \\
\hline Molase & $1: 2$ & $4-5$ & 5 & 5 \\
\hline Molase & $1: 3$ & $4-5$ & 5 & 5 \\
\hline Molase & $1: 4$ & $4-5$ & 5 & 5 \\
\hline Molase & $1: 5$ & $4-5$ & 5 & 5 \\
\hline Glukosa & $1: 1$ & $4-5$ & 5 & 5 \\
\hline Glukosa & $1: 2$ & $4-5$ & 5 & 5 \\
\hline Glukosa & $1: 3$ & $4-5$ & 5 & 5 \\
\hline Glukosa & $1: 4$ & $4-5$ & 5 & 5 \\
\hline Glukosa & $1: 5$ & $4-5$ & 5 & 5 \\
\hline
\end{tabular}

Tabel 4. Hasil uji ketahanan luntur warna terhadap gosokkan

\begin{tabular}{ccccc}
\hline Konsentrasi & \multicolumn{4}{c}{ Nilai penodaan } \\
\cline { 2 - 5 } & \multicolumn{2}{c}{ Molase } & Glukosa $100 \%$ \\
\cline { 2 - 5 } & Kering & Basah & Kering & Basah \\
\hline $1: 1$ & $4-5$ & 4 & $4-5$ & 4 \\
\hline $1: 2$ & $4-5$ & 4 & $4-5$ & 4 \\
\hline $1: 3$ & $4-5$ & 4 & $4-5$ & 4 \\
\hline $1: 4$ & $4-5$ & 4 & $4-5$ & 4 \\
\hline $1: 5$ & $4-5$ & 4 & $4-5$ & 4 \\
\hline
\end{tabular}


Pengujian ketahanan luntur warna terhadap pencucian dilakukan berdasarkan standar SNI ISO 105C06:2010. Hasil pengujian ketahanan luntur warna terhadap pencucian pada kain kapas yang dicelup menggunakan zat warna alam indigo dengan variasi rasio berat zat warna dan reduktor molase dan glukosa pada Tabel 3 menunjukkan nilai perubahan warna 4/5 dan penodaan warna 5 . Ini berarti kain hasil pencelupan dengan zat warna alam indigo memiliki ketahanan luntur warna yang baik. Hal tersebut dikarenakan pada proses pelarutan dengan penambahan reduktor, zat warna indigo yang awalnya tidak larut dalam air diubah menjadi bentuk leuko yang larut dalam air sehingga larutan leuko dapat berdifusi ke dalam serat. Setelah zat warna berikatan dengan serat, dilakukan proses oksidasi yang menyebabkan zat warna kembali kebentuk semula (tidak larut dalam air), akibatnya ketika dicuci, zat warna tidak berinteraksi dengan air. Zat warna indigo yang sudah tercelup pada kapas tidak mengalami kelunturan dikarenakan air lunturan pada proses pencucian hasil pencelupan kapas dengan zat warna indigo merupakan zat warna yang berbentuk tidak larut dalam air sehingga tidak mempunyai substantivitas terhadap serat kapas dan wol.yang digunakan sebagai pelapis.

Pengujian ketahanan luntur warna terhadap gosokan dilakukan berdasarkan standar SNI ISO 105X12:2012. Penodaan pada kain pelapis uji gosokan kering berada pada nilai 4/5, sedangkan untuk gosokan basah berada pada nilai 4 yang berarti baik. Penodaan pada kapas terjadi akibat adanya gerakan mekanik saat proses pengujian dengan gosokan sehingga zat warna lebih mudah lepas. Zat warna yang ada pada permukaan serat akan lebih mudah terkikis dengan adanya gesekan. Kondisi proses pencelupan yang dilakukan pada suhu $30^{\circ} \mathrm{C}$ selama 10 menit mengakibatkan sebagian warna tidak terdifusi sempurna ke dalam inti serat. 
4. Kesimpulan dan Saran

\subsection{Kesimpulan}

Molase yang digunakan untuk pembentukan leuko zat warna indigo mengandung gula pereduksi sebanyak 17,1747\%. Kandungan gula pereduksi pada molase mampu mengubah zat warna indigo yang tidak larut menjadi leuko yang larut yang dapat digunakan untuk proses pencelupan. Makin tinggi rasio berat zat warna dan molase, zat warna indigo makin larut. Kinerja molase didukung dengan ketuaan dan kerataan warna hasil pencelupan yang mengalami peningkatan seiring kenaikan peningkatan rasio molase.

Penggunaan molase tidak berdampak pada ketahanan luntur warna terhadap pencucian dan gosokkan. Dibandingkan dengan glukosa murni, molase masih memiliki daya reduksi lebih rendah.

\subsection{Saran}

Molase dapat digunakan sebagai alternatif reduktor untuk pembentukan leuko zat warna indigo yang ramah lingkungan. Perlu dilakukan penelitian lebih lanjut untuk mengetahui penambahan molase dan pengondisian pada larutan pencelupan untuk mencegah oksidasi dini.

\section{Daftar Pustaka}

1. Aleem, A. (2013). An Investigation of Alternatives to Reductive Clearing in the Dyeing of Polyester. Heriot Watt University.

2. Arta, Tin Kusuma, dkk (2019). Pewarnaan Batik Menggunakan Bubuk Pewarna Alam Indigofera Tinctoria dan Strobilantes Cusia. Dinamika Kerajinan dan Batik Vol. 36 No. 2 Hal. 163-172.

3. Baffoun, Ayda, Mohamed Hamdaoui, Zouheir Romdhani (2015). Use of Glucose as an ecofriendly reducing sugar in the application of Sulphur dyes. Indian J ournal of Fibre \& Textile Research.

4. Bechtold, Thomas \& Rita Mussak. (2009). Handbook of Natural Colorants. Leopold-Franzens University, Austria.

5. B lackburn, R.S., Bechtold, T., J ohn, P. (2009). The development of indigo reduction methods and pre-reduced indigo products. Color. Technol. 125, $193 e 207$.

6. Blackburn, R.S., Harvey, A. (2004). Green chemistry methods in sulfur dyeing: Application of Various Reducing D-sugars and Analysis of the Importance of Optimum Redox Potential. Environ. Sci. Technol. 38, 4034e4039. 
7. Dewi, Elevia Sabrina. (2019). Pengaruh Konsentrasi Reduktor Glukosa dan Waktu Pereduksian terhadap Pelarutan Zat Warna Alam Indigo (Indigofera tinctoria) dan Hasil Pencelupannya menggunakan Kain Kapas Metode Exhaust. Politeknik STTT Bandung.

8. Djufri, R., Kasoenapno, Salihima, A., Lubis, A. (1976). Teknologi Pengelantangan Pencelupan dan Pencapan. Institut Teknologi tekstil. B andung.

9. Garcia P., \& J ohn P. (2004). Formation of Natural Indigo Derived from Woad (Isatis tinctoria L.) in Relation to Product Purity. J . Agric. Food Chem.

10.https://fscimage.fishersci.com/msds/21290.htm diakses pada 25 November 2020

11.Komboonchoo, S. Turcanu, A., Bechtold, T. (2009). The reduction of dispersed indigo by cathodically formed 1,2,4-trihydroxynaphthalene. Dyes Pigments 83, $21 \mathrm{e} 30$.

12. Lestari K, Riyanto. (2004). Pembuatan Pewarna Biru dari Tanaman Indigofera tinctoria. Dinamika Kerajinan dan Batik, Vol. 21, Hh. 7 - 15.

13. Meksi, Meksi, N., Ben Ticha, M., Kechida, M., Mhenni, M.F. (2012). Using of ecofriendly a-hydroxycarbonyls as reducing agents to replace sodium dithionite in indigo dyeing processes. Journal of Cleaner Production, 24, 149-158.

14.Purnama H, Hidayati N, Dyah S. Safitri. (2017). Effect of Initial Treatment in the Preparation of Natural Indigo Dye from Indigofera Tinctoria. Universitas Muhammadiyah Surakarta Indonesia.

15. Rochani, dkk. (2016). Pengaruh Konsentrasi Gula Larutan Molase Terhadap Kadar Etanol Pada Proses Fermentasi. Universitas Tribhuwana Tunggadewi.

16.Shukla \& Roshan. (2004). Sulphur dyeing using non-sulphide reducing agents. Indian J ournal of Fibre \& Textike Research, 29, 454-461. 